\title{
Forgotten Slovakia Civic Initiative: Talking Openly about Extremism. Parallel Monologues or a Discussion on Values?
}

\author{
Monika Vrzgulová \\ Institute of Ethnology SAS
}

"There are as many worlds as those that can fit in your head." The first time I heard this sentence was in 1995, when I began working for the Milan Šimečka Foundation (Nadácia Milana Šimečku) ${ }^{1}$. While I do not remember who said it and on what occasion, it became my life credo. In the mid-1990s, the worlds that I had had in my head changed considerably. As a member of the research team of the international project Oral History: Fates of Those Who Survived (1995-7) (Salner 1997; Vrzgulova 2005, 2016), I began discovering the previously unknown faces of my surroundings, and I am still on this discovery trip. As an ethnologist, I meet and talk to people. And since I am interested in their interpretations and observations of their own life stories, I am intrigued by how large historic events are reflected in personal histories. ${ }^{2}$ While I assume the role of the listener during my research, I also seek to encourage debates during lectures and workshops. I am convinced that only through discussions is it possible to share our own private worlds and get to know each other. An open, decent, substantive, and constructive discussion this is often the ideal that we seek to achieve. This is where we recognize the worlds of the people around us, where we evaluate, criticize, and argue; where we defend our own values and our view of the world, and try to convince others. This is where we listen and react.

I have been combining these two roles since 2016: I discuss and I explore. I have become a member of the civic initiative "Forgotten Slovakia: Open Debates about Extremism" (Zabudnuté Slovensko: otvorené debaty o extrémizme, ZS

\footnotetext{
* Monika Vrzgulová, Institute of Ethnology SAS, Klemensova 19, 81109 Bratislava, Slovak Republic; monika.vrzgulova@savba.sk. In 2017-18, Monika Vrzgulova is Visiting Fellow at the Jack, Joseph, and Morton Mandel Center for Advanced Holocaust Studies, United States Holocaust Memorial Museum.

This text was written as part of the VEGA Project 2/0022/17 "The wartime Slovak State and the Holocaust in the current public discourse (An ethnological view)" and the project of Slovak Academy of Sciences "The Social Analysis of Slovakia 2017".

1 Milan Šimečka Foundation is one of the oldest NGOs in Slovakia, established in February 1991. For more details on the foundation, see www.nadaciamilanasimecku.sk.

2 Over the past 20 years, I have conducted hundreds of interviews using mainly oral history or the biographical method. I seek to capture the memories of witnesses and survivors about their life during the wartime Slovak State, in the post-war period, and during the Communist regime in Slovakia.
} 
initiative or ZS). ${ }^{3}$ It was one of the citizens' reactions to the fact that Kotleba - Our Slovakia People's Party (Kotleba - Ludová Strana Naše Slovensko, LSNS) entered the National Council of the Slovak Republic (Národná rada Slovenskej Republiky, NR SR) based on the results of the past parliamentary elections. The political program and the statements of its representatives clearly present an extremist right-wing orientation (as suggested by the name of the "leader" in the party name). According to statistics, this political party was elected by a considerable number of first-time voters (Gyárfášová, Slosiarik, 2016). One of the segments by which LSNS addressed citizens was the resentment toward the wartime Slovak State (1939-45), its President Jozef Tiso, and the Ludak regime that he represented. The Ludak policy apparently inspired "Kotleba people" ("kotlebovci"- LSNS members named after their chairman, M. Kotleba) in defining the political pillars of their own program. They look innocent at first sight - being national, Christian, and social. A deeper study of their specific declarations and of their media (and other) communications suggests that what they are in fact saying is this: "We don't accept anything other".

The initiators of Forgotten Slovakia invited me to become a member of their team mainly due to my long-term scientific and activist work on the reflection of the wartime Slovak State and the Holocaust in Slovakia in the current public and political discourse. My main findings and knowledge from my participation for more than a year at local debates on extremism can be simply described as follows: citizens from different Slovak regions have insufficiently developed skills necessary for conducting an open discussion. Their knowledge about the past is burdened with stereotypes and prejudice. They are often unable to view the historic events from several perspectives, beyond the perspective of their own reference group. The official historical narrative about the wartime period in the Slovak State and the Holocaust in Slovakia is so ambivalent that it provides room for even contradictory interpretations. It is also evident that a portion of LSNS supporters do not deal with the past; they are only interested in the present. By voting for Kotleba's party, this group wanted to express its protest and hope that a political party, which - in principle - opposes the official establishment, would improve their situation. From discussions with various groups of citizens, we can observe a phenomenon that we call conflicting memories. Translated into the language of common communication, we can state it as follows: people in Slovakia are often unable to allow "the worlds of others" into their minds and, moreover,

3 For more details, see http://www.zabudnuteslovensko.sk/sk/ and https://www.facebook.com/zabudnuteslovensko/ 
they are not even willing to admit their existence. This statement is the result of my active participation and participant observation of the debates on extremism, organized by the Forgotten Slovakia initiative.

\section{The 2016 Elections}

As an ethnologist, I often work in different regions outside Bratislava. I study (among other things) the Holocaust phenomenon and the entire period in which it happened (wartime Slovak State 1939-45) in the social and the respectively cultural memory of the Slovak society (Assmann 2016, 15-44). Even though I had a clear idea in 2016 about the resentments toward the Ludak regime in "the first national state of Slovaks", the election results shocked me - and especially the fact that the preference for this party was voiced by first-time voters.

One week after the elections, I conducted a training course for secondaryschool teachers in the Museum of the Slovak National Uprising in Banská Bystrica. During an informal discussion, some teachers told me that on the Monday following the elections, the school director had called them to his office, blaming them for teaching history incorrectly, and hence being responsible for the fact that some of the those pupils had voted for Kotleba. However ridiculous it may sound, the media articulated similar speculations as well: it was the fault of the teachers that Kotleba' party to the Parliament. I admit that I was also concerned that L'SNS had been backed by young people who had cast their votes for the first time. One need not be a genius to realize that by doing so, young people expressed their discontent with the policies of the standard political parties that have long been in power. Unfortunately, they did so by giving support to a party the representatives of which have made no secret of admiring the undemocratic Ludak regime. And what has been taught about this regime at schools since the 1990s is that it had been responsible for the Holocaust in Slovakia, as well as for the persecution of other population groups in the country! Hence, there are two possibilities: young people either know about this link and do not care, or they are simply not aware of it. My communication with teachers from different Slovak regions, as well as my surveys on the state of knowledge and opinions of the Slovak population on the wartime Slovak State and the Holocaust, ironically confirm that both possibilities may be correct. This part of our past is perceived very ambiguously, and not just by the youngest generations of Slovakia. It also

4 Term used to designate the wartime Slovak State by its admirers from among the members of the current Matica slovenská or by many political representatives and historians - both in Slovakia and abroad. 


\section{Monika Vrzgulová, Forgotten Slovakia Civic Initiative: Talking Openly about}

Extremism. Parallel Monologues or a Discussion on Values?

reflects family interpretations of this history, the recollections of the times when grandparents or grand-grandparents were doing well... However, this situation is the result of an entire set of causes and processes, with education being just one part of it. ${ }^{5}$

In the state of anxiety after the elections, I realized that almost no "established" politician in parliament sought to clearly oppose the representatives of the party with Ludak resentments. It was at that time that I had received the offer from journalist and photographer Andrej Bán. He was contacted by civil activist and architect Michal Karako, a native of Brezno (just like the LSNS party chairman). Together, they invented a reaction to the postelection situation: the Forgotten Slovakia civic initiative, in which I was invited to participate.

The first activity was the public discussion and concert Against Fascism, held symbolically in Brezno on May 8, 2016. The free concert was organized in the main square on the occasion of the defeat of Nazi Germany and the end of World War II in Europe. In between the performances of the music bands, we spoke to the inhabitants of the town from the stage with appeals to not forget the victims of the Second World War and of the Holocaust in Slovakia and persecution after the suppression of the Slovak National Uprising. We also appealed to them to not support political parties that represent extreme dangers for the country, similar to the Nazis or fascists.

The square was filled with chairs in which a diverse group of audience members sat (in terms of age, gender, and ethnicity). They came mostly out of curiosity, yet they stayed and did not leave. We were, however, afraid of an open clash with LSNS supporters and members, but other than a message in the form of party stickers on the chairs in the auditorium, we did not record anything else.

This series continued with events in other Slovak towns - the representatives of the initiative have so far met with the citizens of 15 towns. ${ }^{6}$ We chose towns in which LSNS won more than $10 \%$ of the votes of first-time voters in the election.

5 Detailed analysis of the survey "The Slovak State during WWII in the Slovak Collective Memory of 2013" available at: http://www.holokaust.sk/the-slovak-state-during-wwii-and-the-holocaust-in-theslovak-collective-memory.

6 Until March 2018, the discussions under the Forgotten Slovakia initiative were held in Brezno, Velký Krtîš, Dolný Kubín, Revúca, Žiar nad Hronom, Kežmarok, Ružomberok, Banská Bystrica, Hlohovec, Trnava, Vranov nad Toplou, Bardejov, Čadca, Detva, and Skalica. I have attended seven debates so far. 


\section{Forgotten Slovakia Initiative: The Model for Public Discussion}

The team discussing as part of the Forgotten Slovakia initiative is different each time. Each of us is there as a human, a citizen, and an expert. In the debates, we want to share our opinions on the current events in Slovakia, but we also seek to talk about the causes that have their origin in the recent past and to listen to the opinions of the audience. The core members of the initiative are A. Bán and M. Karako; the other speakers include selected experts (historians, ethnologists, or political scientists), a survivor of the Holocaust, and a person known from the media (a singer, actor, or journalist). We also try to invite a local activist or other personality known to the local audience to the debate.

In principle, the day-trip model is standard. The morning is dedicated to meetings with secondary and elementary school pupils in a cultural center, a cinema, or another public place. The discussion moderator, Bán, first introduces the initiative, its objectives, and participants to the pupils. Right from the beginning he emphasizes the willingness of the speakers to reply to all questions within a decent debate, without any invectives or expressions of violence. The students watch the documentary movie by Marek Šulík, Cesta Magdalény Robinsonovej (The voyage of Magdaléna Robinsonová), which is followed by a discussion. Pupils can send their questions via mobile text messages, which has proved to work very well, and we always have enough questions. The film is an autobiographic testimony of a famous photographer who was transported to the Nazi extermination camp in Auschwitz at a young age. She talks about her experiences and comments on her postwar problems and efforts to reconcile with her own Holocaust experience. She also presents her opinion on the situation in Slovakia at the turn of the 20th and 21 st century and comments on the nationalist and pro-Ludak speeches and statements of the Roman Catholic Church's top representatives regarding the wartime Slovak State in the media. Pupils ask about other details from the life of photographer Robinsonová, since they are also curious about experts' opinions on extremism; it is not clear to them what is dangerous about the political program of Kotleba's party and why it is extreme. Equally frequent is the question on whether we may again face the situation from the end of the 1930s, whether there can be genocide in Europe or in Slovakia again. They also ask questions related to their own firsthand experience (about cohabitation with the Roma minority in their own town) as well as philosophical questions (where was God during the Holocaust). Quite common are widespread stereotypes concerning the misuse of the social welfare system in our country by the Roma, nurtured by LSNS propaganda and by the many so-called alternative media. After the official closure of the debate, students enjoy the 
opportunity to continue debating with the representatives of the initiative personally and on an informal basis. These meetings suggest that many young people take an interest in what is going on in society, and that they often know in person LSNS local political representatives, trying to confront the political opinions of the participants of the initiative. I think it would be interesting to detail their questions asked via text messages and how it affects their courage. The second part of the Forgotten Slovakia trip is an evening meeting with the town citizens. The basic structure of these meetings is similar; what is different is the composition of the audience, which influences the content and the form of the debate. People often come to the meeting according to the speakers whose names are announced in advance. If Fedor Gál, e.g., one of the representatives of the November 1989 events, is present, the meeting is attended by the founders of the local Public Against Violence organization (Verejnost proti násiliu $)^{7}$, such as in Vel'ký Krtís. If we have Roma activists or Roma journalists among the speakers, then there are more Roma people in the audience (such as in Detva). At the first meetings, the people sympathizing with Kotleba's LSNS party or its voters and members did not reveal their identity voluntarily; it was disclosed through the questions they asked or the arguments they used.

During our third or fourth trip (in Dolný Kubín, Ružomberok), they began openly declaring their support for L'SNS. In Kežmarok, the native town of one of the L'SNS parliamentary deputies, they organized a bus trip for their members and supporters to attend the evening discussion.

The topics raised at each public meeting can be split into several areas. The first one concerns the clarification of terms: what is extremism and who is an extremist; what extremism means in politics; and why it is dangerous. Or we talk about the nondemocratic regimes in Slovakia in the 20th century. Since there is always someone who has survived the Holocaust at each discussion, a part of the debate is dedicated to the wartime Slovak State and the Holocaust in Slovakia. Of course, we also talk about the current situation in Slovakia and Europe. People express their concerns and fears about the migration wave from Syria and Africa, as well as their anger and dissatisfaction with the unresolved domestic corruption scandals and causes. According to the manner of formulation of questions and arguments, it is easy to deduce the opinions they identify with and whose fans they are. Another big topical area concerns daily life issues, local topics such as high unemployment, uncooperative citizens of a town, district, or nearby settlement, as well as positive examples

7 Public Against Violence was a political movement established in November 1989 in Bratislava, Slovakia. It was the Slovak counterpart of the Czech Civic Forum (Občanské Fórum). 
of cohabitation or the solution of problematic situations presented by local activists or personalities.

The main idea and impulse for our trips across Slovakia are to demonstrate our interest in those parts of our country where people in general may feel that they have been "forgotten", that they are of no interest to "those over there in Bratislava". An important impetus is the notion that not all voters of Kotleba's party are extremists and that the neo-Ludak sentiment or racist antiRoma attacks are not the primary themes that attract their attention.

I seek to understand local society and its problems through debates. It is about capturing the value orientation of the people involved in the discussions, as well as the causes that influence their opinions. Together with Cliford Geertz, we attempt to carry out a cultural analysis of the local population sample, guess the meaning of their speeches, and formulate (for myself) what they actually try to convey to us (Geertz, 2000, 31).

During field research, I usually assume the role of the listener or observer or the role of the guide through the dialogue. During the Forgotten Slovakia debates, I act as their representative, which is a new experience to me.

This attempt of mine to interpret public expressions and to analyze shared reality within the discussions of the Forgotten Slovakia civic initiative is more exceptional than common. I have outlined my position in the foregoing discussion - I submit my expert knowledge and skills to my civic ambition. I enter into discussions with my fellow citizens, becoming familiar with their value orientation and preferences first hand. I try to explain to them why it is dangerous to support an extremist political party and what consequences it may have on our common future and the character of the whole society. Now, however, I shall elaborate on the regional specifics of the discussion meetings by describing a model discussion and its basic features.

The public space of a town - the hall of a cinema or of a cultural center becomes the place of the voluntary meeting of various groups of people. Their motivations, value orientations, and aims are diverse.

The members of the Forgotten Slovakia civic initiative act as initiators of a common discussion on a predetermined topic. During the discussion, they often act as mediators between the different groups of town citizens. Simply put, these can be divided (according to their verbal and nonverbal communication expressions) into the following categories: LSNS voters, sympathizers, and members; sympathizers of civic initiatives; local civic activists; and the most numerous group comprises those who do not demonstrate their opinions, namely, the silent majority. 
Initially, the representatives of the first group attempted to act as part of a legitimate political alternative. Because we publish the debates on the Internet and LSNS sympathizers or members even record them, we have realized over time that this group of people is very closely knit and prepares for the meetings in a targeted manner. One thing is evident - they refer to what was said in the previous town, wishing to add or explain things. Their reactions are characterized by specific ideological preparation (questioning or trivialization of the Holocaust, questions about the number of Slavic victims during World War II, or questions about President Jozef Tiso) or populist arguments typically used by LSNS representatives (e.g., let us leave the past; we are interested in the current bad situation; Roma delinquency; corruption scandals; migrant threat, threats to Christian Slovakia, and so on).

The second group of actors - people sharing similar values as the representatives of the initiative - discusses specific situations and reacts to arguments, questions, and the speeches of the debaters on site. These actors often directly oppose Kotleba's party and its opinions. The most numerous group of people is usually silent. What does the exchange of opinions and attitudes indicate?

What I commonly observe among local debaters is that they are not accustomed to publicly formulating their own opinions and talking openly in front of a broader audience. Many of them are unable to hold a discussion with people who have a different opinion. Such confrontation is unusual to them, and from time to time, they do not handle it and leave the place of the debate. Smooth communication is also complicated by the fact that the representatives of the civic initiative are perceived as foreigners, as people who have a different life experience than the locals. It reminds me of a conflict of the center, the capital city, with the local people who feel like they are on the periphery. Such communications are penetrated by stereotypes, prejudices, suspicions, and even distrust ("Why didn't you come before Kotleba entered the parliament? Where have you been until now? Have you come to preach to us from your Bratislava feedboxes? Who is paying for this Jewish theater of yours?"). Many local people are unable to understand that we come to discuss with them from our own will, that nobody sends us, that nobody is paying us, and that we are not politicians. The discussions are accompanied by an emotional behavior that has its roots in the problematic daily reality of the local debaters. Such moments clearly show the extent of the conflict in terms of the value orientations and preferences. We search for words and arguments to understand the reality in the same way. It is sometimes very complicated. Our perception of the notions of democracy, freedom (personal freedom, freedom of expression), and their meanings is different, and we 
have a different idea of what it means to live a good and happy life. It is not uncommon to see among local people their preference for social security as a detriment of their own freedom ("I haven't been happy since 1989; we must deal with our problems on our own; I don't like this type of democracy"). LSNS voters react sensitively, while others designate this party as extremist ("I'm not extremist; I'm convinced Kotleba will put everything in order"); the historical parallels or experience from the recent European past (e.g., war in former Yugoslavia) would not help.

During these debates, I realize that people in Slovakia have little knowledge about history and, additionally, that they equal history with their personal or family historical experience. The result, therefore, is parallel - or even contradictory - memories of the same historic period. I consider it the consequence of the phenomenon that I have long been exploring: the official policies of remembrance of the wartime Slovak State and the Holocaust in Slovakia are more-or-less ambiguous. This results in the relativization and unwillingness to speak publicly about this historic period. At the same time, we are lacking a common narrative about the country's Communist past. Hence, the debaters are often unable, and even unwilling, to think about their lived past from the perspective of diverse population groups and their different experiences. And in addition to all the facts I observe and react to, there is one more question that I repeatedly seek to answer: are we not providing too much space with these debates to the supporters and members of the extremist LSNS? Is it correct that we discuss with them? The first time I faced these doubts was after the debate in Ružomberok, where we saw debaters from the previous place who now openly and proudly claimed to belong to the LSNS district organizations. On the way back to Bratislava and during the following days, I raised my doubts several times in conversations with my colleagues from the initiative. I finally accepted the opinion according to which these discussions provide an opportunity to the silent majority, the undecided ones, or those who do not express themselves, that we simply show them that there are also other opinions, other views of the world. I admit that this argument does not always satisfy me.

\section{Conclusion}

If I return now to my favorite sentence, "There are as many worlds as those that can fit in your head", I would like to modify it slightly after my experience from the Forgotten Slovakia discussions: "There are as many worlds as you are willing to allow inside your head". Our meetings in the Slovak towns in which people expressed the biggest support to the extreme right-wing Kotleba party 
confirmed one more thing: the more different the group of debaters in terms of its value orientation, the more complicated the debate is. People can talk to each other if they follow the basic rules of a decent debate; however, if they do not react to each other's arguments and ideas, it is rather a case of parallel monologues than a dialogue. One of the main problems characterizing these meetings is the fact that a thoroughly critical public discussion about the historic experience of Slovakia with two undemocratic regimes that influenced the value orientations, attitudes, behavior patterns, and communication of its inhabitants until the present has in fact not yet begun. There is no targeted effort to deal with our own totalitarian past. Much more can be done by the political elites and other opinion-forming authorities (scientists, church representatives, journalists, or teachers) in society. And maybe now is the time to make change ${ }^{8}$, although I write the word "from the bottom" cautiously - because from the debates during Forgotten Slovakia, I also know the expressions and opinions of the "bottom current". Yet, it is definitely high time to begin to talk and commonly define the term "decent future", as well as agree both on joint actions and on respecting them. Nevertheless, I know from my professional experience that it is easier to agree on what we do not want rather than to come to common terms with what we do want. The vision of a decent future in a decent country is worth some effort, though.

It will not be a short journey. There is, however, one condition at its start: make space for the worlds of people around you inside your heads!

\section{References}

Assmann, Aleida. 2016. Shadows of Trauma: Memory and the Politics of Postwar Identity, New York: Fordham University Press.

Geertz, Clifford. 2000. Interpretace kultur. [The Interpretation of Culture] Praha: SLON.

Gyárfášová, Ol'ga Slosiarik, Martin, eds. 2016. Volby do NR SR 2016: Čo charakterizovalo voličov. [Elections to the National Council of the Slovak Republic 2016: What characterized voters]. Working papers in Sociology, 1, November. Accessed February 15, 2018. http:// www.sociologia.sav.sk/pdf/Working_Papers_in_Sociology_012016.pdf.

Salner, Peter. 1997. Prežili holocaust. [They Survived the Holocaust]. Bratislava: VEDA.

Vrzgulová, Monika. ed. 2005. We Saw the Holocaust. Bratislava: Milan Simecka Foundation.

Vrzgulová, Monika. 2016. Nevyrozprávané susedské pribehy. Holokaust na Slovensku z dvoch perspektiv. [Untold Stories of the Neighbours. Holocaust in Slovakia from Two Perspectives]. Bratislava: VEDA.

8 The author wrote this text in the first half of March 2018, at the time of protest demonstrations in Slovakia provoked by the murder of investigative journalist Ján Kuciak and his fiancée: at the time when politicians were dealing with the government crisis and people expressed in public debates and protests their ideas of a decent Slovakia. 